\title{
Effect of Mn and Fe on Yield, Fruit Quality and Economic Feasibility of Mandarin (Citrus reticulata Blanco) cv. Kinnow
}

\author{
S.C. Gurjar ${ }^{1}$, R.S. Rathore ${ }^{1 *}$, Virendra Singh ${ }^{1}$, Sukhdev Singh $^{1}$, \\ Yogendra Singh ${ }^{2}$, B.S. Bhati ${ }^{3}$ and B.G. Chippa ${ }^{4}$
}

${ }^{1}$ Department of Horticulture, Rajasthan College of Agriculture, MPUAT, Udaipur 313001, Rajasthan, India

${ }^{2}$ Department of Fruit Science, VCSG Uttatakhand University of Horticulture and Forestry, Bharsar 246123, Uttarakhand, India

${ }^{3}$ Krishi Vigyan Kendra, Banswara, India

${ }^{4}$ Directorate of Research, MPUAT, Udaipur, India

\begin{tabular}{|c|c|}
\hline & A B S T R A C T \\
\hline $\begin{array}{l}\text { Manganese, } \\
\text { Ferrous, Yield and } \\
\text { Quality }\end{array}$ & \multirow{3}{*}{$\begin{array}{l}\text { The experiment was carried out at KVK, Chittorgarh, Maharana Pratap University of } \\
\text { Agriculture and Technology, Udaipur, Rajasthan during the year 2016-17. The experiment } \\
\text { consisted of } 9 \text { treatments comprising } \mathrm{T}_{1}-\left(\text { water spray), } \mathrm{T}_{2}-(0.5 \% \text { Manganese sulphate), }\right. \\
\mathrm{T}_{3}-\left(1.0 \% \text { Manganese sulphate), } \mathrm{T}_{4}-\left(0.5 \% \text { Ferrous sulphate), } \mathrm{T}_{5}-(1.0 \% \text { Ferrous }\right.\right. \\
\text { sulphate), } \mathrm{T}_{6}-\left(0.5 \% \mathrm{MnSO}_{4}+0.5 \% \mathrm{FeSO}_{4}\right), \mathrm{T}_{7}-\left(0.5 \% \mathrm{MnSO}_{4}+1.0 \% \mathrm{FeSO}_{4}\right), \mathrm{T}_{8}- \\
\left(1.0 \% \mathrm{MnSO}_{4}+0.5 \% \mathrm{FeSO}_{4}\right), \mathrm{T}_{9}-\left(1.0 \% \mathrm{MnSO}_{4}+1.0 \% \mathrm{FeSO}_{4}\right) \text { applied at fruit set and } \\
\text { pea size stage of fruit through foliar spray. Among the treatments, treatment } \mathrm{T}_{8}(1.0 \% \\
\left.\mathrm{MnSO}_{4}+0.5 \% \mathrm{FeSO}_{4}\right) \text { was best for higher yield and produced best quality fruits. As far } \\
\text { as relative economics of treatments is concerned highest } \mathrm{B}: \mathrm{C}(4.68) \text { was obtained in } \mathrm{T}_{8} \\
\left(1.0 \% \mathrm{MnSO}_{4}+0.5 \% \mathrm{FeSO} \mathrm{S}_{4}\right) \text { and this treatment gave the highest net returns (Rs. } 348114 \\
\left.\mathrm{ha}^{-1}\right) \text { with maximum yield/ ha. }\end{array}$} \\
\hline Article Info & \\
\hline $\begin{array}{l}\text { Accepted: } \\
\text { 20 June } 2018 \\
\text { Available Online: } \\
10 \text { July } 2018\end{array}$ & \\
\hline
\end{tabular}

\section{Introduction}

Kinnow Mandarin" is one of the most important and finest variety of mandarin especially grown in North India. It is the first generation hybrid of king mandarin $(C$. nobilis Lour) and willow leaf mandarin $(C$. deliciosa Tenora) (Sharma et al., 2007). It was developed by H.B. Frost at Regional Fruit Station, California, USA. It was first introduced in India during 1959's at the Fruit Experiment Station, Punjab and Agriculture
College and Research Institute, Lyallpur by S. Bhadur Lal Singh (Singh et al., 1978). Since then it has assumed great importance among north Indian growers and a large acreage is being brought under its cultivation particularly in Punjab, Haryana, Rajasthan and Himachal Pradesh (Khurdiya and Lotha, 1994).

Kinnow is very useful citrus fruit and rich source of vitamin C $(63 \mathrm{mg} / 100 \mathrm{ml})$ to fulfill daily need. Its pulp is used to make delicious desserts, jams and sauces and the skin can be 
used to make cosmetics and essence. It has lycopene and flavonoides, which are known to reduce prostate and breast cancer, viral affects and cholesterol level and improve capillary activity. It is rich in fiber, which is important for production and maintenance of collagen (Sharma et al., 2007).

Foliar application of mineral nutrients is a method for quick supply of the elements for the higher plants. This technique allows the plants to consume nutrients much faster than their uptake from soil by their roots. Despite some shortcoming, it is regarded as the best method under certain conditions (Marschner and Marschner, 2012). The micronutrients are required in small amount but play a great role in plant metabolism (Katyal, 2004; Kazi et al., 2012). These are involved in the synthesis of many compounds essential for plant growth and productivity and act as activators for various enzymes. Manganese is required in the process of photosynthesis (Mengel and Kirkby, 1987) and Ferrous plays a key role in several enzyme-systems, in which haeme or haemin is the prosthetic group (Khurshid et al., 2008).Foliar application of micro and macronutrient like $\mathrm{Zn}, \mathrm{Cu}, \mathrm{Mn}, \mathrm{B}, \mathrm{Fe}$ and $\mathrm{K}_{2}$ Ohas advantages over soil application because of high effectiveness, rapid plant response, convenience and elimination of toxicity symptoms brought about by excessive soil accumulation of such nutrients (Obreza et al., 2010).

Recently numerous complaints have been received from kinnow growers regarding poor fruit set, uneven fruiting, poor quality and low yield of fruits. In different commercially growing regions of Rajasthan, farmers are not applying nutrients in proper quantity, and therefore, some healthy orchards are turning into unproductive orchards with poor yield and poor quality of the produce. The efficient use of nutrients is essential because of their high cost as well as concerns regarding pollution. In Southern Rajasthan, the fruit growers generally apply major nutrients $(\mathrm{N}, \mathrm{P}$ and $\mathrm{K}$ ) in kinnow plants and give little attention towards micronutrients. Due to high $\mathrm{pH}$ and calcareous soil in this region, hinders the availability of the basal applied micronutrients. Therefore, kinnow plants show micronutrient deficiency symptoms like interveinal chlorosis, reduced growth of young shoot and mottling of leaves (Sharma et al., 1990). Keeping in view of the importance of kinnow mandarin in the Southern- Rajasthan, the study has been carried out to see the effect of $\mathrm{Mn}$ and $\mathrm{Fe}$ on it fruit yield, quality and economic feasibility.

\section{Materials and Methods}

The experiment was carried out at Krishi Vigyan Kendra, Chittorgarh and Department of Horticulture, Rajasthan College of Agriculture, MPUAT, Udaipur during 201617. Eight year old, twenty seven uniform and healthy kinnow (king $\mathrm{x}$ willow leaf) mandarin trees grafted on rough lemon (Citrus jambhiri L.) root stock planted according to square system of layout at $5 \mathrm{~m} \times 5 \mathrm{~m}$ distance and grown under uniform soil conditions were selected. The experiment consisted of 9 treatments comprising $\mathrm{T}_{1}$ - (water spray), $\mathrm{T}_{2}$ (0.5\% Manganese sulphate), $\mathrm{T}_{3}-(1.0 \%$ Manganese sulphate), $\mathrm{T}_{4}-(0.5 \%$ Ferrous sulphate), $\mathrm{T}_{5}-\left(1.0 \%\right.$ Ferrous sulphate), $\mathrm{T}_{6}$ $\left(0.5 \% \mathrm{MnSO}_{4}+0.5 \% \mathrm{FeSO}_{4}\right), \mathrm{T}_{7}-(0.5 \%$ $\left.\mathrm{MnSO}_{4}+1.0 \% \mathrm{FeSO}_{4}\right), \mathrm{T}_{8}-\left(1.0 \% \mathrm{MnSO}_{4}+\right.$ $\left.0.5 \% \mathrm{FeSO}_{4}\right), \mathrm{T}_{9^{-}}\left(1.0 \% \mathrm{MnSO}_{4}+1.0 \%\right.$ $\mathrm{FeSO}_{4}$ ) applied at fruit set and pea size stage of fruit through foliar spray. These treatments were evaluated under RBD replicated thrice with adopting uniform cultural schedules during the experimentation.

The fruit yield parameters viz. fruit volume was measured by water displacement method. For this purpose, the fruits were dipped in a fully filled jar of water and the water displaced 
by the fruits was collected and measured by graduated glass jar and the recorded readings was averaged.For fruit retention, total numbers of fruits set on the plant were counted, then the total numbers of fruits were again counted at the time of fruit maturity. The per cent fruit retention was calculated on the basis of initial number of fruit set. The yield plant ${ }^{-1}$ was recorded on the basis of mature fruits harvested periodically in each treatment separately and the weight was recorded with the help of electronic balance then the total yield (kg/plant) was calculated. The quality attributes such as TSS were determined by using a hand refractometer, reducing sugar content was measured using dinitrosalicylic acid. Sugars were extracted with hot 80 per cent ethanol in $100 \mathrm{mg}$ sample. Supernatant was collected and evaporated by keeping on a water bath at $80^{\circ} \mathrm{C}$ and $10 \mathrm{ml}$ water was added.

After dissolving of sugars, $3 \mathrm{ml}$ extract was pipette out and $3 \mathrm{ml}$ DNS reagent was added in $3 \mathrm{ml}$ extract. $1 \mathrm{ml}$ of 40 per cent Rochelle salt solution was added in hot DNS- extract mixture. After cooling, absorbance was measured on spectrophotometer (Double beam SL 210 UV Visible Spectrophotometer) at 510 $\mathrm{nm}$. Total sugar content was determined by using anthrone reagents method. One $\mathrm{ml}$ of diluted sample (100 times), $4 \mathrm{ml}$ of anthrone reagent was added, then heated for 10 to 15 minutes on a water bath, cooled to room temperature and absorbance was measured at $630 \mathrm{~nm}$ on spectrophotometer (Systronics UVVIS spectrophotometer 108).

Ascorbic acid was determined by diluting the known volume of clean juice and titrated against 2, 6-dichlorophenol indophenol dye solution. For rind thickness, ten fruits were randomly selected and peeled out with the help of hand and then it's measured by digital Vernier caliper and expressed in $\mathrm{mm}$.

\section{Results and Discussion}

\section{Effect of manganese and ferrous on fruit yield attributes of kinnow mandarin}

The data presented in Table 1 revealed that maximum fruit volume $(198.00 \mathrm{cc})$, fruit retention $(69.74 \%)$, yield plant $^{-1}(78.23 \mathrm{~kg})$ and estimated yield $\mathrm{ha}^{-1}(31.29 \mathrm{t})$ were recorded in treatment $\mathrm{T}_{8}\left(1.0 \% \mathrm{MnSO}_{4}+0.5\right.$ $\left.\% \mathrm{FeSO}_{4}\right)$ closely followed by $\mathrm{T}_{9}$ over the treatment $\mathrm{T}_{1}$ (control). It might be due to manganese is involved in photosynthesis, efficient use of $\mathrm{N}$, protein metabolism and enzyme activation. Iron acts as a catalyst in oxidation/reduction reactions, involved in respiration, photosynthesis and the reduction of nitrate and sulfate. It is also a cofactor in many enzymes. These are leads to more fruit retention and yield. The present results were supported by the findings obtained by Ghosh and Besra (2000) found that zinc + boron + iron resulted in highest fruit retention $(78.6 \%)$ and fruit plant ${ }^{-1}$ (205) in sweet orange cv. Mosambi. Mn is required in the process of photosynthesis (Mengel and Kirkby, 1987) and Fe plays a key role in several enzymesystems, in which haeme or haemin is the prosthetic group (Khurshid et al., 2008). The increase in yield is obviously due to the consolidated effect of increased size and weight of fruits caused by foliar spray of manganese and ferrous. It is in conformity with the findings of Devi et al., (1997) in satgudi orange, Ingle et al., (2002) in acid lime, Tariq et al., (2007) in sweet orange, Aboutalebi and Hassanzadeh (2013) in sweet lime, Kaur et al., (2015) in kinnow mandarin for various yield attributes.

\section{Effect of manganese and ferrous on fruit quality of kinnow mandarin}

The data presented in Table 2 revealed that maximum TSS $\left(10.93{ }^{\circ} \mathrm{B}\right)$, reducing sugar $(2.96 \%)$, total sugar $(6.59 \%)$, ascorbic acid 
content $(27.08 \mathrm{mg} / 100 \mathrm{~g})$ with minimum rind thickness $(2.79 \mathrm{~mm})$ were recorded in treatment $\mathrm{T}_{8}\left(1.0 \% \mathrm{MnSO}_{4}+0.5 \% \mathrm{FeSO}_{4}\right)$ closely followed by $\mathrm{T}_{9}$ over the treatment $\mathrm{T}_{1}$ (control). The improvement in quality of fruit is might be due to the fact that nutrients directly play an important role in plant metabolism. Manganese activates decarboxylase, dehydrogenase and oxidase enzymes in plants which are important in photosynthesis, nitrogen metabolism and nitrogen assimilation. It is an essential element in respiration and involved in the destruction or oxidation of indole-3-acetic acid (Singh, 2014). The augmentation of ascorbic acid percentage of kinnow fruit might have been due to higher synthesis of nucleic acid, on account of maximum availability of plant metabolism. The findings of present study are in accordance with those of Balakrishnan et al., (1996) in pomegranate, Ghosh and Besra (2000) in sweet orange cv. Mosambi, Monga and Josan (2000) in kinnow mandarin, Perveen and Haffez-ur-Rehman (2000) in sweet orange, Kaur et al., (2015) in kinnow mandarin for various qualities attributes.

Table.1 Effect of manganese and ferrous on fruit yield attributes of kinnow mandarin

\begin{tabular}{|l|l|c|c|c|}
\hline Treatments & Fruit volume (cc) & Fruit retention (\%) & Yield plant $^{-\mathbf{1}} \mathbf{( k g )}$ & Estimated yield (t/ha) $^{(\mathbf{t} / 00}$ \\
\hline $\mathbf{T}_{\mathbf{1}}$ & 165.00 & 58.00 & 62.26 & 24.90 \\
\hline $\mathbf{T}_{\mathbf{2}}$ & 168.00 & 68.42 & 63.49 & 25.39 \\
\hline $\mathbf{T}_{\mathbf{3}}$ & 171.00 & 67.97 & 65.02 & 26.00 \\
\hline $\mathbf{T}_{\mathbf{4}}$ & 179.11 & 67.70 & 69.06 & 27.62 \\
\hline $\mathbf{T}_{\mathbf{5}}$ & 178.00 & 68.50 & 67.22 & 26.88 \\
\hline $\mathbf{T}_{\mathbf{6}}$ & 181.21 & 67.65 & 69.68 & 27.87 \\
\hline $\mathbf{T}_{\mathbf{7}}$ & 180.88 & 69.00 & 75.07 & 30.02 \\
\hline $\mathbf{T}_{\mathbf{8}}$ & 198.00 & 69.74 & 78.23 & 31.29 \\
\hline $\mathbf{T}_{\mathbf{9}}$ & 194.66 & 68.80 & 77.26 & 30.90 \\
\hline $\mathbf{S E m} \pm$ & 5.51 & 1.64 & 2.65 & 1.22 \\
\hline $\mathbf{C D}(\mathbf{p}=\mathbf{0 . 0 5})$ & 16.52 & 4.91 & 7.93 & 3.64 \\
\hline
\end{tabular}

Table.2 Effect of manganese and ferrous on fruit quality of kinnow mandarin

\begin{tabular}{|c|c|c|c|c|c|c|}
\hline Treatments & $\begin{array}{c}\text { TSS } \\
(\mathbf{0} \text { Brix) }\end{array}$ & $\begin{array}{c}\text { Reducing } \\
\text { sugar }(\mathbf{\%})\end{array}$ & $\begin{array}{c}\text { Total sugar } \\
(\mathbf{\%})\end{array}$ & $\begin{array}{c}\text { Non reducing } \\
\text { sugar } \mathbf{( \% )}\end{array}$ & $\begin{array}{c}\text { Ascorbic acid } \\
(\mathbf{m g} / \mathbf{1 0 0} \mathbf{g})\end{array}$ & $\begin{array}{c}\text { Rind thickness } \\
(\mathbf{m m})\end{array}$ \\
\hline $\mathbf{T}_{\mathbf{1}}$ & 9.90 & 2.83 & 5.58 & 2.75 & 19.81 & 3.14 \\
\hline $\mathbf{T}_{\mathbf{2}}$ & 10.10 & 2.74 & 5.96 & 3.22 & 23.42 & 3.20 \\
\hline $\mathbf{T}_{\mathbf{3}}$ & 10.80 & 2.77 & 6.15 & 3.38 & 21.62 & 2.95 \\
\hline $\mathbf{T}_{\mathbf{4}}$ & 10.50 & 2.62 & 5.89 & 3.27 & 21.62 & 3.25 \\
\hline $\mathbf{T}_{\mathbf{5}}$ & 10.70 & 2.68 & 6.10 & 3.42 & 23.42 & 2.86 \\
\hline $\mathbf{T}_{\mathbf{6}}$ & 10.70 & 2.75 & 6.21 & 3.46 & 25.22 & 2.92 \\
\hline $\mathbf{T}_{\mathbf{7}}$ & 10.80 & 2.83 & 6.43 & 3.60 & 27.02 & 2.99 \\
\hline $\mathbf{T}_{\mathbf{8}}$ & 10.93 & 2.96 & 6.59 & 3.63 & 27.08 & 2.79 \\
\hline $\mathbf{T}_{\mathbf{9}}$ & 10.90 & 2.95 & 6.55 & 3.60 & 27.02 & 2.79 \\
\hline $\mathbf{S E m} \pm$ & 0.20 & 0.01 & 0.09 & 0.05 & 0.35 & 0.04 \\
\hline $\mathbf{C D}(\mathbf{p}=\mathbf{0 . 0 5})$ & 0.60 & 0.04 & 0.28 & 0.15 & 1.06 & 0.13 \\
\hline
\end{tabular}


Table.3 Economic feasibility of kinnow mandarin

\begin{tabular}{|c|c|c|c|c|c|c|c|}
\hline Treatments & $\begin{array}{l}\text { General } \\
\text { cost }(A)\end{array}$ & $\begin{array}{l}\text { Cost due to } \\
\text { treatment } \\
\text { (B) }\end{array}$ & $\begin{array}{l}\text { Total cost of } \\
\text { cultivation } \\
(A+B)\end{array}$ & $\begin{array}{c}\text { Estimated } \\
\text { yield } \\
\text { (t/ha) }\end{array}$ & $\begin{array}{c}\text { Gross } \\
\text { return } \\
\left(\text { Rs. } \text { ha }^{-1}\right)\end{array}$ & $\begin{array}{c}\text { Net } \\
\text { return } \\
\left(\text { Rs.ha }^{-1}\right)\end{array}$ & $\mathrm{B}: \mathrm{C}$ \\
\hline $\mathbf{T}_{1}$ & 73760.64 & - & 73760.64 & 24.90 & 336150 & 262389 & 3.55 \\
\hline $\mathbf{T}_{2}$ & 73760.64 & 99 & 73859.64 & 25.39 & 342802 & 268942 & 3.64 \\
\hline $\mathbf{T}_{\mathbf{3}}$ & 73760.64 & 198 & 73958.64 & 26.00 & 350994 & 277036 & 3.74 \\
\hline $\mathbf{T}_{4}$ & 73760.64 & 341.88 & 74102.52 & 27.62 & 372863 & 298761 & 4.03 \\
\hline $\mathbf{T}_{5}$ & 73760.64 & 683.87 & 74444.51 & 26.88 & 362880 & 288436 & 3.87 \\
\hline $\mathbf{T}_{6}$ & 73760.64 & 440.88 & 74201.52 & 27.87 & 376246 & 302045 & 4.07 \\
\hline $\mathbf{T}_{7}$ & 73760.64 & 782.87 & 74543.51 & 30.02 & 405274 & 330731 & 4.43 \\
\hline $\mathbf{T}_{8}$ & 73760.64 & 539.88 & 74300.52 & 31.29 & 422415 & 348114 & 4.68 \\
\hline $\mathbf{T}_{9}$ & 73760.64 & 881.87 & 74642.51 & 30.90 & 417143 & 342501 & 4.58 \\
\hline
\end{tabular}

Sale of kinnow fruits @ Rs.13.50/kg.

\section{Economic feasibility in kinnow mandarin}

Data presented in Table 3 revealed that among the treatments maximum net returns (Rs. $348114 \mathrm{ha}^{-1}$ ) was obtained under treatment $\mathrm{T}_{8}\left(1.0 \% \mathrm{MnSO}_{4}+0.5 \% \mathrm{FeSO}_{4}\right)$, while minimum net returns (Rs. 262389 ha $^{-1}$ ) was obtained in control, with respect to maximum $\mathrm{B}: \mathrm{C}$ ratio (4.68) was recorded in $\mathrm{T}_{8}$ $\left(1.0 \% \mathrm{MnSO}_{4}+0.5 \% \mathrm{FeSO}_{4}\right)$ closely followed by treatment $\mathrm{T}_{9}$ (4.58), $\mathrm{T}_{7}$ (4.43), $\mathrm{T}_{6}$ (4.07) and $\mathrm{T}_{4}$ (4.03) as compared to minimum (3.26) in control.

\section{References}

Aboutalebi, A. and Hassanzadeh, H. 2013. Effects of iron and zinc on sweet lime (Citrus limmettoides) fruit quantity and quality in calcareous soils. International Journal of Farming and Allied Sciences, 2(18): 675-677.

Balakrishnan, K., Venkatesan, K. and Sambandamurthis, S. 1996. Effect of foliar application $\mathrm{Zn}, \mathrm{Fe}, \mathrm{Mn}$ and $\mathrm{B}$ on yield quantity of pomegranate, $c v$. Ganesh. Orissa Journal of Horticulture, 24: 33-35.

Devi, D.D., Srinivasan, P.S. and Balkrishan, K. 1997. Effect of zinc, iron and manganese on yield and quality of sweet orange cv. Sathgudi. Madras Agricultural Journal, 84(8): 460-463.

Ghosh, S.N. and Besra, K.C. 2000. Effect of zinc, boron and iron spray on yield and fruit quality of sweet orange $c v$. Mosambi grown under rainfed laterite soil. Indian Agriculturist, 44(3/4): 147151.

Ingle, H.V., Kokate, S.S., Athwale, R.B. and Katole, S.R. 2002. Effect of foliar application of zinc and iron on growth, yield and quality of acid lime. Indian Journal of Citriculture, 1(1): 43-45.

Katyal, J.C. 2004. Role of micronutrients in ensuring optimum use of macronutrients. IFA International Symposium on Micronutrients, Feb. 23-25, New Delhi, India, pp: 3-17.

Kaur, N., Monga, P.K., Arora, P.K. and Kumar, K. 2015. Effect of micronutrients on leaf composition, fruit quality and yield of kinnow mandarin. Journal of Applied and Natural Science, 7(2): 639-643.

Kazi, S.S., Ismail, S. and Joshi, K.G. 2012. Effect of multi-micronutrient on yield and quality attributes of the sweet orange. African Journal of 
Agricultural Research, 7(29): 4118-4123.

Khurdiya, D.S and Lotha, R.E. 1994. Effect of juice extraction from Kinnow mandarin on the composition and quality of juice pomace and peel. Journal of Food Science \&Technology,71: 307-330.

Khurshid, F., Khattak, R.A. and Sarwar, S. 2008. Effect of foliar applied (Zn, Fe, $\mathrm{Cu} \& \mathrm{Mn})$ in citrus production. Science Technology \& Development, 27(1\&2): 34-42.

Marschner, H. and Marschner, P. 2012. Marschner's Mineral nutrition of higher plants. Third edition, Elsevier, p. 651, Academic Press, Amsterdam.

Mengel, K. and Kirby, E.A. 1987. Principles of Plant Nutrition, pp: 453-461. International Potash Institute, Berns, Switzerland.

Monga, P.K. and Josan, J.S. 2000. Effect of micronutrients of leaf composition, fruit yield and quality of Kinnow mandarin. Journal of Applied Horticulture, 2(2): 132-133.

Obreza, T.A., Zekri, M., Hanlon, E.A., Morgan, K., Schumann, A. and Rouse, R. 2010. Soil and leaf tissue testing for commercial citrus production. University of Florida Extension Service, SL: 253-254.
Perveen, S. and Haffez-ur-Rehman. 2000. Effect of foliar application of zinc, manganese and boron in combination with urea on the yield of sweet orange. Pakistan Journal of Agriculture Research, 16(2): 135-141.

Sharma, K.K., Sharma, K.N. and Nayyar, V.K. 1990. The effect of copper and zinc sprays on leaf nutrient concentration in Kinnow mandarin (Citrus reticulata x Citrus deliciosa). Indian Journal of Horticulture, 60(4): 278-80.

Sharma, S., Singh, B., Rani, G., Zaidi, A.A., Hallan, V., Nagpal, A. and Virk, G.S. 2007. Production of Indian citrus ringspot virus free plants of Kinnow employing chemotherapy coupled with shoot tip grafting. Central European Agriculture Journal, 8: 1-8.

Singh, B.P., Gupta, A.K. and Chundawat, B.S. 1978. Effect of various treatments on storage of Kinnow fruits. Punjab Horticulture Journal, 18(5): 61-65.

Tariq, M., Sharif, M., Shah, Z. and Khan, R. 2007. Effect of foliar application of micronutrients on the yield and quality of sweet orange (Citrus sinensis L.). Pakistan Journal of Biological Sciences, 10(11): 1823-1828.

\section{How to cite this article:}

Gurjar, S.C., R.S. Rathore, Virendra Singh, Sukhdev Singh, Yogendra Singh, B.S. Bhati and Chippa, B.G. 2018. Effect of Mn and Fe on Yield, Fruit Quality and Economic Feasibility of Mandarin (Citrus reticulata Blanco) cv. Kinnow. Int.J.Curr.Microbiol.App.Sci. 7(07): 28152820. doi: https://doi.org/10.20546/ijcmas.2018.707.329 